\title{
Some Useful Sources
}

\section{Stephen Crossley* and Michael Lambert**}

\author{
*School of Applied Social Sciences Durham University \\ E-mail: s.j.crossley@durham.ac.uk \\ ** Department of History, Lancaster University \\ E-mail:m.lambert@lancaster.ac.uk
}

This useful sources section focuses on four key areas related to the Troubled Families Programme: official government documents and sources of information relating to the programme; emerging academic research relating specifically to the implementation of the programme; sources which help to locate the programme in its wider historical context; and international perspectives which provide information on how 'troubled families' are viewed in different countries. The sources listed here hopefully add to and complement the bibliographies of the individual articles in this section.

\section{Government troubled families documents}

Government documents, progress reports, speeches and press releases relating to the Troubled Families Programme can be found on the 'Support for families' webpage (https://www.gov.uk/government/policies/support-for-families).

\section{Some key official documents are:}

Department for Communities and Local Government (DCLG) (2012a) Listening to Troubled Families, London: DCLG.

Department for Communities and Local Government (DCLG) (2012b) Working with Troubled Families, London: DCLG.

Department for Communities and Local Government (DCLG) (2013) The Fiscal Case for Working with Troubled Families, London: DCLG.

Department for Communities and Local Government (DCLG) (2014a) Understanding Troubled Families, London: DCLG.

Department for Communities and Local Government (DCLG) (2014b) Financial Framework for the Expanded Troubled Families Programme, London: DCLG.

Department for Communities and Local Government (DCLG) (2015) The Benefits of the Troubled Families Programme to the Taxpayer, London: DCLG.

House of Commons Committee of Public Accounts (2014) Programmes to Help Families Facing Multiple Challenges, HC 668, London: The Stationery Office.

National audit Office (2013) Programmes to Help Families Facing Multiple Challenges, London: The Stationery Office. 


\section{The Troubled Families Programme}

Arthur, R. (2015) 'Troubling times for young people and families with troubles - responding to truancy, rioting and families struggling with adversity', Social Legal Studies, 24, 3, 443-64.

Ball, E., Batty, E. and Flint, J. (2016) 'Intensive family intervention and the problem of figuration of "Troubled Families"', Social Policy and Society, 15, 2, 263-74.

Bond-Taylor, S. (2014) 'The politics of "anti-social" behaviour within the "Troubled Families" Programme', in S. Pickard (ed.), Anti-Social Behaviour in Britain: Victorian and Contemporary Perspectives, Basingstoke: Palgrave.

Bond-Taylor, S. (2015) 'Dimensions of family empowerment in work with so-called "Troubled Families"', Social Policy and Society, 14, 3, 371-84.

Butler, I. (2014) 'New families, new governance and old habits', Journal of Social Welfare and Family Law, $36,4,415-25$.

Casey, L. (2013) 'Working with troubled families', Families, Relationships and Societies, 2, 3, 459-61.

Casey, L. (2014) 'The National Troubled Families Programme', Social Work and Social Sciences Review, $17,2,57-62$.

Churchill, H. (2015) 'Turning lives around? The Troubled Families Programme', in L. Foster, A. Brunton, C. Deeming and T. Haux (eds.), In Defence of Welfare 2, Bristol: Policy Press, 28-31.

Crossley, S. (2015) "Realising the (troubled) family", "crafting the neoliberal state"', families, relationships and societies', advanced access http://dx.doi.org/10.1332/ $204674315 \times 14326465757666$.

Crossley, S. (2016) 'Realising the (troubled) family: crafting the neoliberal state', Families, Relationships and Societies, 5, 2, 263-79.

Crossley, S. (2016) 'The Troubled Families Programme: in, for and against the state?', in M. Fenger, J. Hudson and C. Needham (eds.), Social Policy Review 28: Analysis and Debate in Social Policy, Bristol: Policy Press.

Gregg, D. (2015) Troubled Families: State Lies, Demonization and Voodoo Social Engineering, Wirral: Green Man Books.

Hayden, C. and Jenkins, C. (2013) 'Children taken into care and custody and the "troubled families" agenda in England', Child and Family Social Work, 20, 4, 459-69.

Hayden, C. and Jenkins, C. (2014) 'Troubled Families Programme in England: "wicked problems" and policy-based evidence', Policy Studies, 35, 6, 631-49.

Levitas, R. (2012) There May be Trouble Ahead: What we Know about those 120,000 'Troubled Families', http://www.poverty.ac.uk/sites/default/files/attachments/WP\% 20Policy\%20Response $\% 20$ No,3-\%20\%20\%27Trouble\%27\%20ahead\%20\%28Levitas\% 20Final\%2021April2012\%29.pdf.

Levitas, R. (2014) 'Troubled Families' in a Spin, http://www.poverty.ac.uk/sites/default/ files/attachments/Troubled\%20Families\%20in\%20a\%20Spin.pdf.

McKendrick, D. and Finch, J. (2016) "'Under heavy manners?": social work, radicalisation, troubled families and non-linear war', British Journal of Social Work, advanced access doi:10.1093/bjsw/bcv141.

Wills, R., Whittaker, A., Rickard, W. and Felix, C. (2016) 'Troubled, troubling or in trouble: the stories of "Troubled Families"', British Journal of Social Work, advanced access doi:10.1093/bjsw/bcw061. 


\section{Historical context}

Bagguley, P. and Mann, K. (1992) 'Idle thieving bastards? Scholarly representations of the "underclass"', Work, Employment and Society, 6, 1, 113-26.

Jordan, B. (1974) Poor Parents, London: Routledge.

Macnicol, J. (1987) 'In pursuit of the underclass', Journal of Social Policy, 16, 3, 293-318.

Macnicol, J. (1999) 'From "problem family" to "underclass" 1945-95', in H. Fawcett and R. Lowe (eds.), Welfare Policy in Britain: The Road from 1945, Basingstoke: Macmillan, 69-93.

Mann, K. (1994) 'Watching the defectives: observers of the underclass in the USA, Britain and Australia', Critical Social Policy, 14, 41, 79-99.

Mann, K. and Roseneil, S. (1994) 'Some mothers do 'ave 'em: backlash and the gender politics of the underclass debate', Journal of Gender Studies, 3, 3, 317-31.

Morris, L. (1994) Dangerous Classes: The Underclass and Social Citizenship, London: Routledge.

Murray, C. (1996) Charles Murray and the Underclass: The Developing Debate, London: IEA.

Philp, A. F. and Timms, N. (1957) The Problem with the Problem Family, London: Family Service Unit.

Rutter, M. and Madge, N. (1976) Cycles of Disadvantage: A Review of Research, London: Heinemann.

Starkey, P. (2000) 'The feckless mother: women, poverty and social workers in wartime and post-war England', Women's History Review, 9, 3, 539-57.

Welshman, J. (2013) Underclass, 2nd edn, London: Bloomsbury.

\section{International approaches to family support}

Daly, M. (2013) 'Parenting support policies in Europe', Families Relationships and Societies, 2, 2, 159-74.

De Regt, A. (1982) 'Unacceptable families: on the origins of social maladjustment', Netherlands Journal of Sociology, 18, 139-56.

Hyslop, I. K. (2016) 'Where to social work in a brave new neoliberal Aotearoa'? Aotearoa New Zealand Social Work, 28, 1, 5-12.

Join-Lambert, H. (2016) 'Parental involvement and multi-agency support services for high-need families in France', Social Policy and Society, 15, 2, 317-29.

Knijn, T. and Hopman, M. (2015) 'Parenting support in the Dutch "participation society"', Social Policy and Society, 14, 4, 645-56.

Lundqvist, A. (2015) 'Parenting support in Sweden: new policies in old settings', Social Policy and Society, $14,4,657-68$.

Martin, C. (2015) 'Parenting support in France: policy in an ideological battlefield', Social Policy and Society, 14, 4, 609-20.

Molinuevo, D. (2013) Parenting Support in Europe, Dublin: Eurofound.

Ostner, I. and Stolberg, C. (2015) 'Investing in children, monitoring parents: parenting support in the changing German welfare state', Social Policy and Society, 14, 4, 621-32.

Sihvonen, E. (2016) 'Early interventionist parenting support: the case study of Finland', Families, Relationships and Societies, advanced access http://dx.doi.org/10.1332/204674316X14552878034703.

Tausendfreund, T., Knot-Dickscheit, J., Schulze, G. C., Knorth, E. J. and Grietens, H. (2016) 'Families in multi-problem situations: backgrounds, characteristics, and care services', Child and Youth Services, 37, 1, advanced access doi:10.1080/0145935X.2015.1052133.

Van Wel, F. (1992) 'A century of families under supervision in the Netherlands', British Journal of Social Work, 22, 2, 147-66. 